\title{
Presynaptic control of nociceptor signalling: Differential influence of mu opioid and GABAergic systems
}

\author{
Ruth C Riley $\mathrm{PhD}^{1}$, Jodie A Trafton $\mathrm{PhD}^{2}$, Allan I Basbaum $\mathrm{PhD}^{2}$
}

\author{
RC Riley, JA Trafton, AI Basbaum. \\ Presynaptic control of nociceptor signalling: \\ Differential influence of mu opioid and GABAergic systems. \\ Pain Res Manage 2000;5(3):185-196.
}

The relative contribution of pre- and postsynaptic controls to the flow of nociceptive information at the level of the spinal cord has been one of Ron Melzack's longstanding interests and a key issue in the formulation of the gate control theory. The authors review their own studies, in which they monitored internalization of the neurokinin-1 receptor to examine specifically the action of two classically inhibitory systems - mu opioid and gamma-amino butyric acid (GABA) - on noxious stimulus-evoked tachykinin signalling in the rat spinal cord. Evidence that opioids and GABAergic controls operate differently on the central consequences of any noxious stimulus-induced substance $\mathrm{P}$ release is provided. Whereas at least $80 \%$ of the tachykinin signalling remained intact after even the highest concentration of spinal morphine or D-Ala2, NMe-phe4, Glyol5-enkephalin administration, spinal administration of the $\mathrm{GABA}_{\mathrm{B}}$ receptor agonist baclofen had a dramatic inhibitory effect. These findings are discussed in light of the disappointing clinical utility of baclofen and neurokinin-1 receptor antagonists to combat pain.

Key Words: Gamma-amino butyric acid; Mu opioid; Neurokinin 1 receptors; Receptor internalization; Spinal cord; Tachykinins

\section{Commande présynaptique de la transmission des signaux par les nocicepteurs : mécanisme d'action des opioïdes de type mu et du GABA}

Le rôle relatif des commandes pré- et postsynaptiques dans la transmission des signaux nociceptifs dans la moelle épinière, en plus de susciter l'intérêt soutenu de Ron Melzack, a constitué un pilier de la théorie du « portillon ». Les auteurs ont passé en revue leurs propres études dans lesquelles ils se sont penchés sur l'endocytose des récepteurs de la neurokinine 1 afin d'étudier le mécanisme d'action de deux inhibiteurs classiques, les opioïdes de type mu et l'acide gammaaminobutyrique (GABA), sur la transmission de la tachykinine déclenchée par un stimulus nocif dans la moelle épinière du rat. Ils ont recueilli des preuves selon lesquelles les opioïdes et le GABA agissent différemment sur les effets centraux de la libération de la substance $P$, provoquée par un stimulus nocif. Tandis qu'au moins $80 \%$ de la transmission des signaux par la tachykinine étaient restés intacts même après les concentrations les plus fortes de morphine dans la moelle épinière ou après l'administration d'enképhaline D-Ala2-Nme-ph4Glyol5, l'administration d'un agoniste des récepteurs du $\mathrm{GABA}_{\mathrm{B}}$ dans la moelle épinière, le baclofen, a eu un effet inhibiteur marqué. Suit une discussion à la lumière des résultats cliniques décevants du baclofen et des inhibiteurs des récepteurs de la neurokinine 1 dans la lutte contre la douleur.
T $\mathrm{t}$ is difficult to pick a topic to discuss that adequately honLours Ron Melzack's many years of pain research. This is particularly problematic if one is cognizant of the tremendous emphasis that Ron puts on the distinction between pain and nociception. Indeed, the thread that binds so many of Ron's studies is that the complexity of the pain experience will not be understood if one exclusively concentrates on the processing of nociceptive messages at the level of the periphery or spinal cord. Ron always emphasized the importance of affective and cognitive components of the pain experience. These elements of the pain experience, so beautifully and memorably discussed in Melzack and Casey's (1) theoretical review, must always be included when this topic is addressed. Dr Allan Basbaum was a student of Ron's in an undergradu-

\footnotetext{
${ }^{1}$ Neuroscience Section, Division of Biomedical Sciences, St Bartholomew's and The Royal London School of Medicine and Dentistry, Queen Mary and Westfield College, London, United Kingdom; ${ }^{2}$ Departments of Anatomy and Physiology and WM Keck Foundation Center for Integrative Neuroscience, University of California San Francisco, San Francisco, California, USA

Correspondence and reprints: Dr Allan Basbaum, Department of Anatomy, University of California San Francisco, 513 Parnassus Avenue, Box 0452, San Francisco, California 94143, USA. Telephone 415-476-5270, fax 415-476-4845, e-mail aib@phy.ucsf.edu
} 
ate class at McGill University, Montreal, Quebec. The topic was motivation. It is still easy to recall the enthusiasm of the lecturer and of the students. The complexity of our perceptions and the influence of that experience on perceptions were common themes of the course. This was true whether the discussion was about the famous hawk-goose experiments of the German ethologists or the maladaptive behaviours of the beagles that Ron raised in restrictive environments (2). These animals would approach a hot flame repeatedly, apparently unable to adapt to these stimuli or appreciate that they were the source of the pain that was generated. Habituation was altered to such an extent that previously experienced stimuli (even 'painful' stimuli) always appeared novel. Apparently, noxious stimuli were not perceived as painful, but not because the stimulus was not transmitted faithfully (ie, nociceptive processing was intact). Clearly an understanding of spinal circuitry and neurochemistry could not, by itself, explain the behaviour of these dogs.

Of course, Ron did not ignore the obvious contribution of nociceptive processing to the experience of pain. Despite his emphasis on the contribution of the brain to the experience of pain, his most famous legacy is the 'gate control theory of pain' (presented in an article co-authored by Pat Wall), which concentrates on dorsal horn circuitry (3). Students today can probably describe gate control theory's dorsal horn circuitry, through which large diameter afferents were hypothesized to regulate the output of the ' $\mathrm{T}$ ' cell - probably a lamina $\mathrm{V}$ neuron in present day terminology. Indeed, nociceptive processing and segmental regulatory mechanisms generated in the dorsal horn are currently the topic of much research and, in fact, are the focus of the present article. But the spinal cord 'gate' is also influenced by supraspinal controls (the 'central control trigger'). This 'trigger' regulated nociceptive processing via activation of cortical and subcortical mechanisms that are put into play through experience. It is not important whether the specific pathways that were hypothesized have proven to be true. What was important was the emphasis on the cortical and limbic contributions to the experience of pain. Basbaum and Fields' (4) studies on the descending control of nociceptive processing were strongly influenced by the pioneering principles that the 'central control trigger' concept articulated.

We hope that Ron is not disappointed with the following discussion that we have written in his honour. The review focuses almost exclusively on the spinal cord networks through which nociceptive inputs are regulated. In some respects, it is a modern day look at how to close the 'gate' that is located in the superficial dorsal horn. Interestingly, it focuses on the balance of pre- and postsynaptic controls of nociceptive messages by dorsal horn neurons - a topic that burned intensely in the debate that arose soon after the publication of the gate control theory paper. In keeping with the ultimate conclusion that both pre- and postsynaptic controls are important, we provide evidence that opioids and gamma-amino butyric acid (GABA)ergic controls operate differently on the central consequences of noxious stimulus-induced substance P (SP) release.

\section{PHARMACOLOGICAL CONTROLS OF PRIMARY AFFERENT NEUROTRANSMITTER RELEASE}

In the quest for new and improved analgesics with minimal side effects, considerable attention has been directed at which systems can regulate neurotransmitter release from the central terminals of primary afferent nociceptors (5). Methods used have ranged from studying how candidate agents affect neurotransmitter release in vivo and in vitro to electrophysiological studies monitoring dorsal root ganglion (DRG) responsiveness and postsynaptic neuronal firing. Although glutamate is almost certainly the primary mediator of nociceptive transmission at this first synapse, other neurochemicals, notably the tachykinin peptides SP and neurokinin (NK) A, are major contributors $(6,7)$. These peptides are present in a proportion of the small primary afferent neurons that terminate in the outer laminae of the dorsal horn, lamina I and lamina II $(8,9)$; are released by high intensity stimulation (10-16); enhance the excitability of spinal neurons to noxious inputs (17-19); and contribute to a 'window' of noxious stimulus-evoked behaviours (20). SP and glutamate colocalize in the terminals of small diameter primary afferent neurons in the dorsal horn $(21,22)$.

Investigations into which systems influence tachykinin release (the majority assaying SP release) have often produced conflicting findings. Among the many molecules that purportedly regulate SP release are noradrenaline, serotonin and neuropeptide $Y$ (5). This article focuses only on the action of two classically inhibitory systems, mu opioid and GABA. We highlight recent studies from our laboratory that used a novel neuroanatomical approach to evaluate the contribution of SP to nociceptive processing. Most importantly, rather than assessing the release of SP, we monitored a marker of the functional consequences of the interaction of SP with postsynaptic dorsal horn neurons - NK-1 receptor internalization.

\section{INTERNALIZATION OF NK-1 RECEPTOR: A RELIABLE MEASURE OF THE FUNCTIONAL CONSEQUENCES OF SP RELEASE}

A range of methodologies have been used to study the release of SP from sensory afferents in vitro or in vivo. Commonly, these have involved measuring the levels of SP in perfusate collected from slices of spinal cord (23), from intact spinal cord (10), or from within the spinal cord tissue itself using push-pull cannulae or microdialysis fibres $(24,25)$. To improve the spatial resolution within which the sites of SP release can be detected, another method was developed that uses immobilized antibodies to SP on microelectrodes. The antibodies bind any locally released peptide and, thus, provide a spatial marker of the locus of peptide release. Importantly, this technique is associated with relatively minor tissue damage, which can induce the release of primary afferent neurotransmitters (26). However, even these 'antibody microprobes' can only measure extrasynaptic levels of peptide. As a result, although an inhibition of SP release may be mirrored by a reduction in peptide levels detected in the perfusate or by reduced binding to microprobes, none of these 

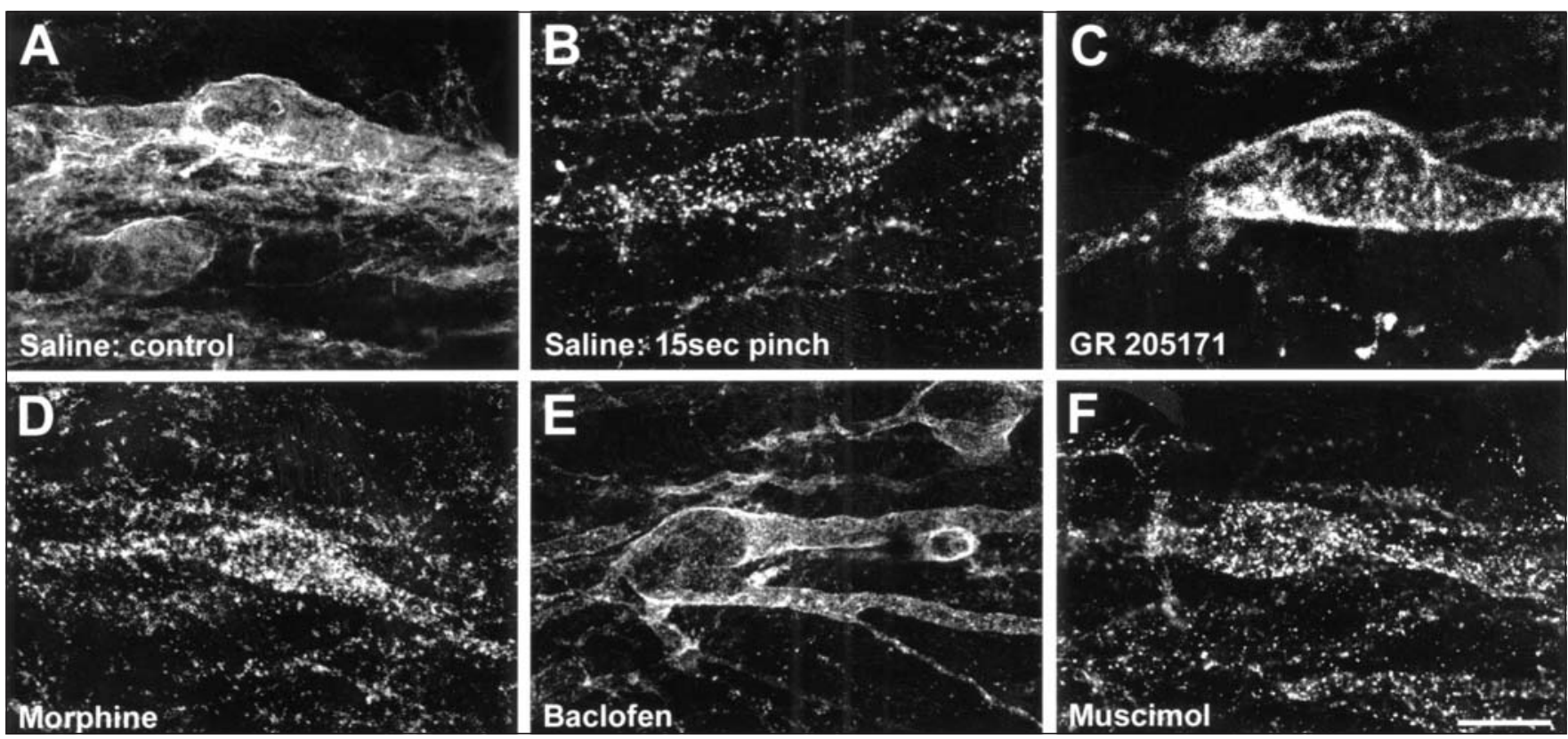

Figure 1) These confocal images (A-F) illustrate the effect of mu opioid and gamma-amino butyric acid (GABA) receptor agonists on noxious stimulus-evoked internalization of the neurokinin (NK) -1 receptor in neurons of lamina I of the spinal cord, viewed here in saggital section. In the absence of, or contralateral to, the side of a noxious stimulation, NK-1 receptor-like immunoreactivity is localized to the plasma membrane (A). However, after noxious stimulation of the periphery, the immunoreactivity is present in endosomal-like structures throughout the cell body, and little or no plasma membrane labelling is evident (B). Receptor internalization is reduced by the systemic administration of the NK-1 receptor antagonist GR205171 (10 mg/kg, subcutaneously) (C). Neither systemic nor spinal morphine had a significant effect on the incidence of NK-1 receptor internalization (30 $\mu \mathrm{g}$ intrathecally) (D). In contrast, spinal administration of the $\mathrm{GABA}_{\mathrm{B}}$ receptor agonist baclofen $(10 \mu \mathrm{g}$ intrathecally) (E) but not the GABA $\mathrm{A}$ receptor agonist muscimol (10 $\mu \mathrm{g}$ intrathecally) (F) dramatically reduced the magnitude of NK-1 receptor internalization. All animals were subjected to a noxious mechanical compression of the distal hindpaw for $15 \mathrm{~s}$ and perfused 5 min later. Drugs were injected either directly into the intrathecal space $(20 \mu \mathrm{L})$ or subcutaneously in $1.0 \mathrm{~mL}$ saline, approximately 20 to $25 \mathrm{~min}$ before stimulation. Scale bar (shown in F) $=20 \mu \mathrm{m}$

techniques can predict the functional consequences of this reduced SP release. Only by monitoring the neurons that respond to the released peptide can this be determined.

The majority of the primary afferent-released SP is thought to act via NK-1 receptors located in the spinal cord dorsal horn. NK-1 receptors are part of a larger family of NK receptors, including the NK-2 and NK-3 receptors that, respectively, show high affinity for NKA and the nonprimary afferent-derived tachykinin NKB (27). As is characteristic of many other G-protein coupled receptors, NK-1 receptors rapidly internalize upon agonist binding (28-30). After internalization, the receptor dissociates from the ligand. The receptor recycles to the plasma membrane (within approximately $1 \mathrm{~h}$ of internalization); the ligand is typically shuttled to lysosomes, where it is degraded. Our group and others have used internalization of the NK-1 receptor as a quantifiable indicator of when neurons that express these receptors are activated in vivo (31-33). In the absence of internalization, NK-1 receptor-like immunoreactivity (NK1R-LI) is uniformly distributed on the surface of cell bodies and dendrites in lamina I (Figure 1A). This was confirmed in electron microscopic studies that also showed that there is a significant mismatch between the presence of SP terminals and the NK-1 receptor; the latter had a much more extensive distribution (34), suggestive of extrasynaptic transmission $(35,36$, but see 37). In fact, despite the presence of dense SP immu- noreactivity in lamina II (the substantia gelatinosa), the only element that expresses the NK-1 receptor in this region corresponds to the dorsally directed dendrites of large NK-1 receptor-expressing neurons in lamina III $(38,39)$.

After noxious stimulation of the rat hindpaw, the distribution of the receptor is dramatically altered. The majority of the immunoreactivity is then present as bright immunofluorescent 'endosome-like' structures in the cytoplasm (Figure 1B). Because the dendrites of these lamina I neurons arborize in the rostrocaudal direction, the incidence of internalization is usually quantified on sections cut in the saggital plane, each neuron being scored for the presence or absence of internalized receptor. In agreement with the consensus of previous studies of SP release (see above), all modalities (mechanical, thermal or chemical) of noxious, but not innocuous, peripheral stimulation were found to induce internalization of the NK-1 receptor $(31,32,40)$. The internalization is dependent on ligand binding; coadministration of the selective NK-1 receptor antagonist GR 205171 significantly reduced noxious stimulus-induced internalization of the NK-1 receptor in spinal cord neurons (Figure 1C) (32).

In the absence of tissue damage, only NK-1 receptors expressed by lamina I neurons show any evidence of internalization after noxious stimulation; however, in the setting of tissue inflammation or nerve injury, NK-1 receptors located more ventrally, in laminae III to VI, also begin to internalize 
in response to noxious stimulation $(32,41,42)$. In some cases, innocuous stimuli applied to inflamed tissue may evoke NK-1 receptor internalization, but exclusively in lamina I. More recently, Schwei et al (43) found that palpation of the limb of a rat with a cancerous femur was an effective stimulus to drive the internalization process. The source of the SP that produced NK-1 receptor internalization in response to innocuous stimuli was unclear in these studies. Several possibilities are proposed. First, there may be peripheral sensitization of the SP-containing primary afferent nociceptor. Second, because there is evidence of de novo synthesis of tachykinins by large diameter, myelinated afferents in the setting of persistent inflammation (44), it is possible that the condition of bone cancer alters the neurochemical phenotype of mechanoreceptors. Finally, the possibility that interneurons and/or descending fibres (45-47) are the source of the SP that induces internalization in novel populations cannot be ruled out. These neurons may be activated by innocuous stimuli in the setting of injury.

Our assumption that receptor internalization provides a robust indicator of the extent of NK-1 receptor activation is based on studies in vitro linking NK-1 receptor internalization to intracellular signalling (48-51). However, all these studies used transfected non-neuronal cell lines, and comparable investigations had not been performed using neurons. To ensure that our endpoint of internalization correlated with NK-1 receptor-mediated signalling, we performed a series of in vitro studies using primary cultures of spinal cord neurons. In these studies, we compared the dose-response curves for the magnitude of SP-mediated increases in intracellular calcium ion and NK-1 receptor internalization. Importantly, we showed that SP-induced calcium ion mobilization was highly correlated with the magnitude of SP-induced NK-1 receptor internalization in dorsal horn neurons. In addition, we showed that the NK-1 receptor antagonist GR 205171 reduced the incidence of noxious stimulus-induced internalization of the NK-1 receptor in a dose-dependent manner. Thus, in contrast to traditional release methods that monitor the extrasynaptic levels of SP (ie, the spillover from that necessary for receptor activation), NK-1 receptor internalization provides a measure of the functional consequences of the SP interaction with the NK-1 receptor.

\section{OPIOID CONTROL OF NOCICEPTOR SIGNALLING}

Radioligand binding studies (52-57), and more recently immunocytochemical (58-65) and in situ hybridization studies (66-69), have located opioid receptors on the cell bodies and terminals of primary afferent neurons, including some small diameter capsaicin-sensitive afferents $(54,55,64)$ that synthesize SP $(58,59,69)$. Minami and co-workers (69) investigated by double in situ hybridization the extent to which each of the mu, delta and kappa subtypes of opioid receptor colocalizes with preprotachykinin A (PPTA), the precursor protein of SP. They found that, whereas $90 \%$ and $30 \%$ of PPTApositive neurons expressed mu and kappa receptor mRNAs at high levels, respectively, only about $3 \%$ of PPTA mRNA- positive neurons expressed delta receptor mRNA at high levels. In addition, electrophysiological studies on cultured or dissociated DRG neurons have shown that opioids active at $\mathrm{mu}$, delta and kappa receptors can suppress voltagedependent calcium ion channel conductances (70-72), which would be expected to contribute to a reduction of neurotransmitter release at the presynaptic terminal. Further, by recording the responses of trigeminal ganglion neurons retrogradely labelled from the tooth pulp, which represents a nearly pure nociceptive population, mu opioid receptor (MOR) regulation of calcium ion channels has been proposed to be limited to the slow-conducting, unmyelinated (C fibre) nociceptors (73)

That opioids reduce a calcium ion conductance is consistent with the demonstration that mu opioids, such as morphine, can inhibit the potassium ion-evoked release of SP from brain slices of the trigeminal nucleus caudalis (74). This key observation led to the hypothesis that inhibition of SP release at the presynaptic terminal is a major mechanism by which opiates produce analgesia. The hypothesis gained support from a number of other investigations that measured the levels of evoked tachykinin (typically SP) in perfusate collected from the spinal cord in vivo $(10,13,75,76)$. However, as Duggan (5) noted, in all these studies, morphine was added to the superfusate from which the levels of SP were subsequently estimated. No group has reported a reduction of stimulus-evoked release of SP when morphine was administered intravenously in analgesic doses $(25,77,78)$. Additionally, other studies in slices failed to find a uniform inhibition of SP release by mu opioids $(23,79,80)$. By contrast, a multiphasic modulation of SP release by morphine has been proposed (80).

\section{OPIOIDS ONLY MINIMALLY AFFECT NOXIOUS STIMULUS-EVOKED NK-1 RECEPTOR INTERNALIZATION}

In light of the questions raised by Duggan (5) and because there is now a measure of SP-mediated signalling, we re-examined the question of the regulation of SP effects by opioids. If there is a functionally relevant presynaptic inhibitory control of SP release, this should be reflected in a reduction of noxious stimulus-evoked internalization of the NK-1 receptor. In these studies, we used acute noxious mechanical or thermal stimulation to evoke SP release, both in normal rats and in rats with a persistent hindpaw inflammation. In contrast to the majority of SP release studies cited above, we found that neither spinal nor systemic morphine had a significant effect on the incidence of NK-1 receptor internalization in lamina I neurons of the lumbar spinal cord (Figure 1D) (33). Only intrathecal administration of high doses of morphine $(30 \mu \mathrm{g})$ resulted in a small, albeit significant, reduction in the percentage of lamina I neurons that contain internalized NK-1 receptors after mechanical stimulation of the hindpaw in normal rats. Importantly, the same result was obtained whether the occurrence of internalization was estimated by our usual 'all or none' criterion, namely scoring neurons as internalized if they contained greater than a threshold number 

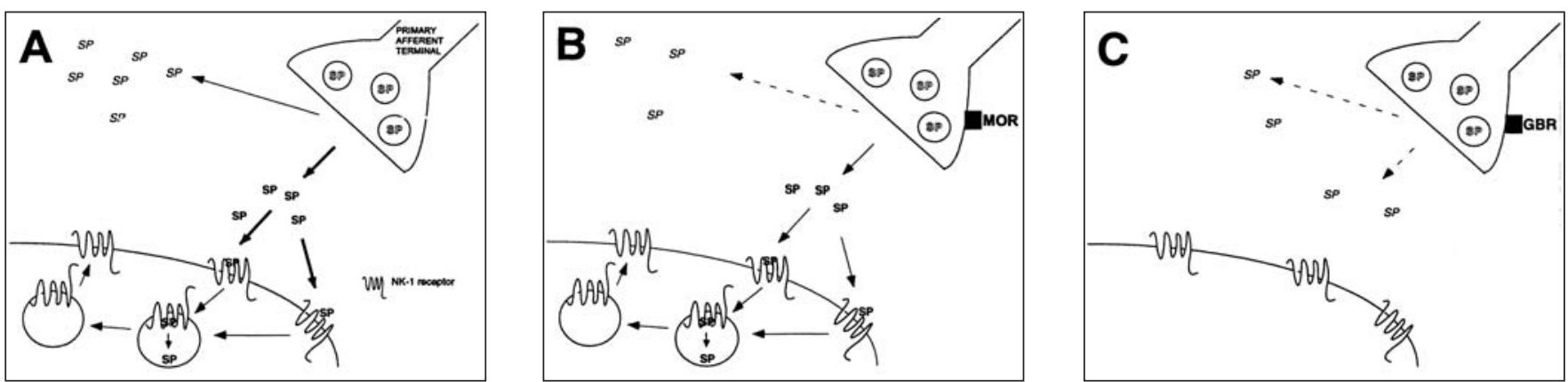

Figure 2) This schematic diagram illustrates the hypothesized mechanisms through which regulation of substance $P$ (SP) release from primary afferents by presynaptic mu opioid receptor (MOR) or gamma-amino butyric acid (GABA) $\mathrm{B}$ receptors (GBR) differentially affects neurokinin (NK)-1 receptor internalization. In the absence of exogenous drugs (A), noxious stimulation of the periphery results in the release of SP (SP) from the terminals of small diameter, unmyelinated primary afferents. Some of this SP (SP) diffuses to target cells, where it interacts and activates NK-1 receptors. This SP is internalized along with the NK-1 receptor into endosomes. Acidification of these endosomes dissociates the SP from the NK-1 receptor. The SP is degraded, and the NK-1 receptor is recycled to the membrane. Unbound SP $(S P)$ diffuses into the extracellular space and eventually into the cerebrospinal fluid, where it may be broken down by endopeptidases. In the presence of the MOR agonist morphine (B), the amount of SP released by noxious stimulation is reduced but not to a sufficient extent to limit the internalization of the postsynaptic NK-1 receptors. In other words, the functional pool of SP is sufficient for near maximal activation and internalization of NK-1 receptors. In contrast, after the spinal administration of the GABAB agonist baclofen, very little SP is released; therefore, little or no SP is available to activate the NK-1 receptors

of NK-1 receptor-positive endosomal-like structures, or when we counted the total number of NK-1-containing endosomes per neuron. In fact, no difference in the average number of NK-1 receptor-positive endosomes per neuron between groups was found.

In subsequent studies, we found that only high concentrations of the selective mu receptor agonist D-Ala2, NMephe4, Glyol5-enkephalin (DAMGO) $(1.0 \mu \mathrm{g})$, but neither the selective delta agonist [D-Pen(2), D-Pen(5)]-enkephalin (DPDPE) $(30 \mu \mathrm{g})$ nor the selective kappa receptor agonist U$50488 \mathrm{H}(100 \mu \mathrm{g})$ decreased the number of neurons with internalized receptor. This suggests that the minimal effect of morphine was mediated by the MOR. Despite reports of enhanced morphine potency following inflammatory injury (81), morphine was less effective in the setting of injury (see below). All these doses of morphine and selective opioid receptor agonists have been found to produce analgesia in animals (82). Because at least $80 \%$ of the tachykinin signalling was estimated to remain intact after even the highest concentration of spinal morphine administration, it was concluded that NK-1 receptor signalling is only slightly reduced under conditions of profound opioid analgesia.

We have argued that it is the magnitude of the inhibition of release that is critical. We do not disagree with the claim that morphine reduces the release of SP from primary afferent nociceptors. However, even when a reduction of the level of SP in cerebrospinal fluid can be detected, the residual SP (presumably at the synaptic cleft) is of sufficient magnitude to exert maximal signalling (and NK-1 receptor internalization) in postsynaptic neurons (Figure 2B). To test this hypothesis specifically, morphine $(10 \mathrm{mg} / \mathrm{kg})$ and an ineffective dose of the NK-1 receptor antagonist GR 205171 $(1.0 \mathrm{mg} / \mathrm{kg})$ were administered simultaneously. The concurrent administration of these drugs significantly reduced the percentage of lamina I cells showing internalization following mechanical stimulation of the hindpaw compared with that in the saline-treated group ( $45 \%$ in the L4-L5 segment) (33). Thus, an ineffective dose of NK-1 receptor antagonist 'uncovered' the relatively large decreases in total SP released. Consistent with this proposal was the finding that this combination of morphine and GR 205171 in rats with persistent hindpaw inflammation was no longer able to reduce significantly the incidence of NK-1 receptor internalization; the highest dose of NK-1 receptor antagonist $(10 \mathrm{mg} / \mathrm{kg})$ administered alone produced less of a reduction. Conceivably, this latter result occurred because of the concurrent upregulation of SP in DRG (83-85) and NK-1 receptor in dorsal horn cells (86-89) in the setting of inflammation. This increased SP release would be expected to reduce the effectiveness of the competitive NK-1 receptor antagonist.

The results of these studies led to the conclusion that opioids produce their analgesic effect predominantly via postsynaptic inhibitory controls that are exerted upon dorsal horn neurons. Of course, presynaptic inhibitory controls of primary afferents that do not release SP cannot be ruled out. Opioid regulation of the release of glutamate, which coexists with SP in some nociceptors, may also contribute. However, overall there is limited electrophysiological evidence to support a direct inhibitory action of opioids on the central terminals of small diameter myelinated and unmyelinated primary afferents $(90,91)$. Rather, opioids, at least MOR-preferring ligands, have mainly been reported to have hyperpolarizing actions on dorsal horn neurons by increasing outward potassium conductance (92-97).

\section{GABAERGIC SYSTEMS IN THE SUPERFICIAL DORSAL HORN}

Given that opioids were found to have little effect on SP signalling, it was of interest to compare their effects with those of other neurochemicals also proposed to exert inhibitory controls on the flow of nociceptive information in the spinal cord. There is a significant body of literature to support the 
possibility that GABA, a major inhibitory neurotransmitter in the central nervous system (CNS), like the MORs, exerts presynaptic control of SP-containing nociceptors (reviewed in 98). GABA operates chiefly through one of two receptor subtypes. The $\mathrm{GABA}_{\mathrm{A}}$ receptor is a ligand-gated ion channel receptor that elicits fast inhibitory postsynaptic currents by increasing the membrane conductance to chloride ion; the $\mathrm{GABA}_{\mathrm{B}}$ receptor is a G-protein-coupled receptor that generates inhibitory potentials of slower onset and more prolonged duration. These may involve the opening of adjacent, inwardly rectifying potassium ion channels, the closure of voltage-dependent calcium ion channels and/or the inhibition of adenylate cyclase (99). Both $\mathrm{GABA}_{\mathrm{A}}$ and $\mathrm{GABA}_{\mathrm{B}}$ receptors have been reported to exert presynaptic actions on nerve terminals, for example, in the CA1 region of the hippocampus, in the molecular layer of the cerebellum, and in the dorsal horn of the spinal cord and trigeminal caudalis $(99,100)$.

Early binding studies using titrated muscimol and baclofen (selective agonists for the $\mathrm{GABA}_{\mathrm{A}}$ and $\mathrm{GABA}_{\mathrm{B}}$ receptors, respectively) provided some evidence for a presynaptic location for both receptors on capsaicin-sensitive (ie, small diameter) primary afferent terminals $(101,102)$. This binding accounted for a high percentage of $\mathrm{GABA}_{\mathrm{B}}$ sites in the dorsal horn (approximately $40 \%$ to $50 \%$ [102]), but less for $\mathrm{GABA}_{\mathrm{A}}$ (approximately $20 \%$ to $30 \%$ [101]). Dorsal rhizotomy produced a reduction in $\mathrm{GABA}_{\mathrm{B}}$-binding sites in the superficial laminae comparable with that produced by neonatal capsaicin treatment, suggesting that these presynaptic $\mathrm{GABA}_{\mathrm{B}} \mathrm{re}-$ ceptors are preferentially localized to capsaicin-sensitive, small diameter myelinated and unmyelinated, typically nociceptive, afferents (103). Even though the $\mathrm{GABA}_{\mathrm{B}}$ receptor has recently been cloned (104), the precise location of the receptor in DRG neurons has yet to be investigated fully by in situ hybridization or immunohistochemistry. By contrast, $\mathrm{GABA}_{\mathrm{A}}$ receptors appear to be more ubiquitously expressed by sensory afferents, as shown by quantification of receptor subunit mRNAs in DRG (105). At an electrophysiological level, studies in vitro (106-108) as well as in vivo (109-113) support both $\mathrm{GABA}_{\mathrm{A}}$ and $\mathrm{GABA}_{\mathrm{B}}$ receptor-mediated effects on nociceptor function. Other groups have, however, described a preferential presynaptic action of the selective $\mathrm{GABA}_{\mathrm{B}}$ receptor agonist, baclofen, on monosynaptic (typically low threshold, large diameter afferent-mediated, proprioceptive) pathways in the spinal cord $(114,115)$.

Studies of the effect of GABA receptor agonists on SP release have produced inconsistent findings. In part, the different conclusions may have resulted from differences in the route of drug administration, as well as in the types of release methodologies used in these studies. For example, whereas studies in vivo failed to demonstrate an effect of systemically administered baclofen on SP release $(13,116)$, those involving the application of baclofen onto spinal cord slices reported dramatic reductions in superfusate levels of SP (117, but see 118,119$)$. In a similar way, direct spinal $(100,120)$ but not systemic (116) injection of baclofen has been reported to reduce the release of calcitonin gene-related peptide
(CGRP), a more generalized marker of small diameter primary afferents (121). Likewise, previous reports on the effect of $\mathrm{GABA}_{\mathrm{A}}$ agonists (muscimol and isoguvacine) on neurotransmitter release have been inconsistent, and overall have reported no effect $(117,122$, but see 13,118$)$. In part, this may reflect the more complex action of $\mathrm{GABA}_{\mathrm{A}}$ receptor agonists on primary afferents. While the role of presynaptic $G_{A B A}$ receptors appears to be exclusively inhibitory, reducing neurotransmitter release via reduction of a calcium ion conductance $(106,123,124)$, the consequence of activating presynaptic $\mathrm{GABA}_{\mathrm{A}}$ receptors is more controversial. Because the $\mathrm{GABA}_{\mathrm{A}}$ receptor antagonist bicuculline inhibits the primary afferent depolarization (PAD) produced in the dorsal grey matter of the spinal cord after an intense afferent volley (125), PAD is likely mediated by $\mathrm{GABA}_{\mathrm{A}}$ receptor, via some shunting of the membrane conductance to chloride ion (126). However, the functional significance of PAD is not clear; it has been implicated in both excitatory (113) and inhibitory $(112,115)$ events.

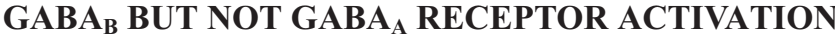 LIMITS NOXIOUS STIMULUS-EVOKED NK-1 RECEPTOR INTERNALIZATION}

To address the contribution of $\mathrm{GABA}_{\mathrm{A}}$ and $\mathrm{GABA}_{\mathrm{B}}$ receptor activation to SP-mediated signalling in the spinal cord dorsal horn, we again monitored the internalization of the NK-1 receptor after acute noxious mechanical or thermal stimulation of the rat hindpaw. In agreement with the majority of SP release studies cited above, there was evidence for a $\mathrm{GABA}_{\mathrm{B}}$ but not $\mathrm{GABA}_{\mathrm{A}}$ receptor-mediated inhibition of tachykinin release and/or signalling in the superficial dorsal horn. Intrathecal administration of $\mathrm{R}(+)$ baclofen $(10 \mu \mathrm{g})$ dramatically reduced the percentage of NK1R-LI lamina I neurons that contained internalized receptors after an acute noxious mechanical stimulation of the rat hindpaw (Figure 1E). By contrast, administration of even high doses of the $\mathrm{GABA}_{\mathrm{A}}$ receptor agonists muscimol $(10 \mu \mathrm{g})$ or isoguvacine $(50 \mu \mathrm{g}) \mathrm{did}$ not produce an effect (Figure 1F). The inhibitory effect by baclofen was prevented by the coadministration of a selective $\mathrm{GABA}_{\mathrm{B}}$ receptor antagonist, CGP55845 $(10 \mu \mathrm{g})$, confirming the selectivity of the effect to $\mathrm{GABA}_{\mathrm{B}}$ receptors (127). These effects are consistent with those seen by Marvizon et al (128), who examined the effect of GABA agonists on NK-1 receptor internalization induced by electrical stimulation of dorsal roots in a spinal cord slice preparation. The robustness of the inhibitory effect of baclofen on tachykinin signalling is illustrated not only by how ineffective opioids are on NK-1 receptor internalization under similar noxious conditions (as presented above), but also by how comparable the maximal reduction of NK-1 receptor internalization produced by intrathecal baclofen (approximately 73\% in L4-L5) is with that produced by the NK-1 receptor antagonist GR205171 (approximately $78 \%$ in L4 [32]).

Although baclofen is predominantly used as a muscle relaxant for the treatment of spasticity in humans (100), it exerts potent analgesic actions in animal models of acute (129131) and persistent pain (132-135), especially when given by 
the spinal route (131). In our studies, although motor sideeffects were found to occur at the higher doses of intrathecal baclofen tested, lower doses, which produce minimal or no motor weakness, and have also been shown to be analgesic $(129,130)$, still significantly reduced the incidence of receptor internalization after noxious stimulation. In keeping with the findings of previous groups $(13,116,119)$, we found that systemic administration of baclofen was only minimally effective in limiting the internalization of the NK-1 receptor, although motor effects were still evident. We conclude that baclofen can exert a powerful inhibitory influence on nociceptor activity and tachykinin release via presynaptic actions at $\mathrm{GABA}_{\mathrm{B}}$ receptors located on the small diameter nociceptive afferents that terminate in the superficial dorsal horn (Figure 2C).

\section{IS THERE TONIC CONTROL OF PRIMARY AFFERENT NEUROTRANSMITTER RELEASE?}

While release studies that monitor the effect of exogenously administered compounds are informative from a pharmacological perspective, they do not address the physiological relevance of these inhibitory controls, ie, whether such modulation occurs in vivo (5). To this end, there is a notable lack in the superficial dorsal horn of axo-axonic synapses in which the presynaptic terminal contains enkephalin (an endogenous ligand of mu and delta opioid receptors) (136139). Instead, in the cat spinal cord, enkephalin-LI axonal boutons have been found presynaptic to physiologically identified nociresponsive neurons in the superficial dorsal horn (139). These are primarily thought to be of intrinsic origin (140-142). More recently, ultrastructural analyses in the rat trigeminal dorsal horn have demonstrated that MORs are more often found postsynaptic to, but infrequently located on, SP-containing terminals in laminae I and II, and that a third of these MOR-positive dendrites colocalize the NK-1 receptor (35). This synaptic arrangement may provide the basis for the MOR inhibition of nociceptor signalling proposed in this review. Of course, the possibility of diffusion of neuronal-released enkephalin to more distant targets must be considered, and is certainly likely given the nonsynaptic interactions that characterize other peptide neurotransmitter systems, including the tachykinins $(143,144)$. On the other hand, because we found minimal control of tachykinin release by exogenously administered opioids, our results suggest that the anatomy may accurately reflect the functional endogenous circuitry, ie, that mu opioids primarily modulate the postsynaptic responses to primary afferent-released SP and glutamate, rather than their actual release. Conceivably, circulating opioids from the pituitary and adrenal medulla may be the source of the endogenous activation of MORs on primary afferents $(139,145)$.

In sharp contrast and in keeping with the dramatic effects of $\mathrm{GABA}_{\mathrm{B}}$ receptor agonists on tachykinin signalling reported here, there is strong evidence that GABAergic neurons are positioned to presynaptically regulate SP-containing primary afferent terminals. Notably, GABAergic terminals make axo-axonic synapses with small diameter primary afferent terminals in the substantia gelatinosa (146-150), some of which may be unmyelinated $(148,150)$ and contain SP (150, but see 151-154). The proposed sources of the GABA are the terminals of 'islet cell' interneurons of laminae II and III in the rat spinal cord (155), although a contribution from descending GABAergic projections (156) cannot be ruled out. There is also morphological evidence to suggest that small diameter primary afferents activate GABAergic interneurons of the superficial dorsal horn $(149,150,152,157,158)$.

Indeed, based on this evidence, it has been proposed that this circuit underlies a negative feedback mechanism that limits the further release of excitatory amino acids and/or peptides from the primary afferent nociceptor (100). Because the majority of NK-1 receptor-positive neurons in the spinal cord, including lamina I, are not GABA-immunoreactive (159), this pathway is likely to be indirect. Increases in the superfusate levels of SP (132) and glutamate (122) from spinal cord slices have been reported following $\mathrm{GABA}_{\mathrm{B}}$ receptor antagonist administration. However, this potentiation of SP release was only evident three weeks after intraplantar injections of Freund's complete adjuvant (132), and no such potentiation of CGRP release by $\mathrm{GABA}_{\mathrm{B}}$ receptor antagonists was observed (98). More recently, Marvizon et al (128) monitored the internalization of the NK-1 receptor in superfused dorsal horn slices and found that 2-hydroxysaclofen (a selective $\mathrm{GABA}_{B}$ receptor antagonist) altered the stimulusresponse function for inducing NK-1 receptor internalization. Normally ineffective, low frequency stimulation (1.0 or $10 \mathrm{~Hz}$ ) of dorsal roots at $\mathrm{C}$-fibre intensities in the presence of 2-hydroxysaclofen induces NK-1 receptor internalization of comparable, if not greater, magnitude than that produced by high frequency stimulation $(100 \mathrm{~Hz})$ in the absence of the antagonist.

We addressed the question of whether there is tonic control of primary afferent neurotransmitter release in our in vivo studies using different modalities (mechanical compared with thermal) and intensities $\left(45^{\circ} \mathrm{C}\right.$ compared with $50^{\circ} \mathrm{C}$ ) of noxious stimulation in the presence of CGP55845. We were unable to detect even a trend toward an increase in the number of neurons with internalized NK1R-LI. Although a recent study reported an increase in the expression of the immediate early gene protein, Fos, induced by peripheral noxious stimulation (160), because the $\mathrm{GABA}_{\mathrm{B}}$ receptor antagonist CGP35348 was administered systemically in that study, the locus of the antagonism could not be determined. It may involve $\mathrm{GABA}_{\mathrm{B}}$ receptors at the brainstem as well as the spinal level (131). Thus, we believe that it is still to be proved whether $\mathrm{GABA}_{\mathrm{B}}$ receptor-mediated tonic regulation of acute nociceptive processing occurs in vivo.

\section{CLINICAL IMPLICATIONS}

Unlike morphine and other mu receptor opioids, $\mathrm{GABA}_{\mathrm{B}}$ receptor agonists such as baclofen have proved to be disappointing in the treatment of human clinical pain (100). Interestingly, this dichotomy in preclinical compared with clinical effectiveness is also true for the use of NK-1 receptor 
antagonists as analgesics (161). These findings, taken together with the results using NK-1 receptor internalization, suggest that disruption of tachykinin signalling is not essential or sufficient for effective analgesia. The possibility remains, however, that blockade of NK-1 signalling can potentiate the actions of morphine, as supported by a number of preclinical $(20,162,163)$ and clinical (164) studies. This may be partly due to differences in the neuronal pathways targeted by these agents. Indeed, using Fos as marker of neuronal activation following noxious peripheral stimulation, we found that, whereas lamina I neurons that express the NK1 receptor are sensitive to baclofen treatment, they are relatively refractory to opioid treatment (33), particularly the ones that project to the parabrachial nucleus (165). In addition, in recent studies using mice carrying a disruption of the preprotachykinin A gene, we found that tachykinins only come into play at relatively high stimulus intensities (20).

Thus, although it remains to be proved that $\mathrm{GABA}_{\mathrm{B}}$ receptor-mediated tonic regulation of nociceptive processing can occur in vivo, the profound inhibitory effects of exogenous baclofen that we observed must not be underestimated. We believe that the search for new approaches in the treatment of persistent pain will be enhanced by further studies that address this form of GABAergic control in primates and humans. Indeed, an understanding of why baclofen is not particularly useful in the treatment of pain (rather than spasticity) in patients may provide important insights into the specific contribution of tachykinin systems to clinical pain conditions.

\section{CONCLUSIONS}

Gate control theory stimulated the research that led to our new appreciation of the complexity of nociceptive processing. This theory emphasized the basic principle of gating that is a hallmark of the transmission of nociceptive messages in the dorsal horn. Our understanding of the complexity of gating, of course, has changed considerably. The 'gate' of gate control theory was part of a hardwired circuit that controlled the flow of nociceptive information in the dorsal horn. The key to opening and closing the gate corresponded to a neuron in the substantia gelatinosa. Thirty-five years of research

\section{REFERENCES}

1. Melzack R, Casey KL. Sensory motivational and central control determinants of pain: A new conceptual model. In: Kenshalo D, ed. The Skin Senses. Springfield: CC Thomas, 1968.

2. Melzack R, Scott TH. Effects of early experience on the response to pain. J Comp Physiol Psychol 1957;50:155-61.

3. Melzack R, Wall PD. Pain mechanisms: a new theory. Science 1965;150:971-9.

4. Basbaum AI, Fields HL. Endogenous pain control mechanisms: review and hypothesis. Ann Neurol 1978;4:451-62.

5. Duggan AW. Release of neuropeptides in the spinal cord. Prog Brain Res 1995;104:197-223.

6. Hylden JL, Wilcox GL. Intrathecal substance P elicits a caudallydirected biting and scratching behavior in mice. Brain Res 1981;217:212-5.

7. Rusin KI, Jiang MC, Cerne R, Randic M. Interactions between excitatory amino acids and tachykinins in the rat spinal dorsal horn. Brain Res Bull 1993;30:329-38. since publication of the theory has taught us that the dorsal horn nociceptive circuits are remarkably plastic - not hardwired. The circuits change subtly through use and dramatically in the setting of injury because of molecular and cellular alterations of the component neurons. More important, perhaps, is that we have learned that there are multiple keys to opening and closing the gate and that the locks are changeable, but the focus of the modern day dorsal horn locksmiths remains the substantia gelatinosa. Understanding gating mechanisms in the dorsal horn, we believe, is still critical to understanding nociceptive processing and to the development of novel therapeutic agents for the treatment of pain.

There is no question that pain is one of the most interesting areas of neuroscience in which to work, and there is also no question that Ron Melzack continues to influence how we think about this fascinating problem. Our own studies are built upon the insights into the relationship between nociception and pain that Ron Melzack has so clearly articulated. Of course, how the output of these dorsal horn circuits is translated into altered perceptions of pain and where in the brain such processing occurs are fascinating questions that should not be ignored and indeed are the focus of Ron Melzack's research to this day. To some extent, our concentration on spinal cord circuitry is one of expedience. Studying the neurochemistry and circuitry in the thalamus and cortex in the context of the 'pain' percept is extremely difficult, particularly in animals. We are aware that nociception and pain are not equivalent and that changes in the expression of a particular gene or of the internalization of a particular receptor do not equate with pain. On the other hand, we believe that a practical approach to developing new treatment regimens will be greatly benefited by studies that characterize the circuitry through which nociceptive messages are processed.

ACKNOWLEDGEMENTS: This work was supported by the National Institutes of Health NS 14627. Dr Riley is the recipient of a Wellcome International Prize Traveling Research fellowship. Dr Trafton was supported in part by a National Science Foundation Predoctoral fellowship and by an Achievement Awards for College Scientists scholarship.

8. Hökfelt T, Kellerth JO, Nilsson G, Pernow B. Experimental immunohistochemical studies on the localization and distribution of substance P in cat primary sensory neurons. Brain Res 1975;100:235-52.

9. Dalsgaard CJ, Haegerstrand A, Theodorsson-Norheim E, Brodin E, Hökfelt T. Neurokinin A-like immunoreactivity in rat primary sensory neurons; coexistence with substance P. Histochemistry 1985;83:37-9.

10. Yaksh TL, Jessell TM, Gamse R, Mudge AW, Leeman SE. Intrathecal morphine inhibits substance $\mathrm{P}$ release from mammalian spinal cord in vivo. Nature 1980;286:155-7.

11. Kuraishi Y, Hirota N, Sato Y, Kaneko S, Satoh M, Takagi H. Noradrenergic inhibition of the release of substance $P$ from the primary afferents in the rabbit spinal dorsal horn. Brain Res 1985;359:177-82.

12. Kuraishi Y, Hirota N, Sato Y, Hanashima N, Takagi H, Satoh M. Stimulus specificity of peripherally evoked substance P release from the rabbit dorsal horn in situ. Neuroscience 1989;30:241-50. 
13. Go VL, Yaksh TL. Release of substance $P$ from the cat spinal cord. J Physiol (Lond) 1987;391:141-67.

14. Duggan AW, Hendry IA, Morton CR, Hutchison WD, Zhao ZQ. Cutaneous stimuli releasing immunoreactive substance $\mathrm{P}$ in the dorsal horn of the cat. Brain Res 1988;451:261-73.

15. Duggan AW, Hope PJ, Jarrott B, Schaible HG, Fleetwood-Walker SM. Release, spread and persistence of immunoreactive neurokinin A in the dorsal horn of the cat following noxious cutaneous stimulation. Studies with antibody microprobes. Neuroscience 1990;35:195-202.

16. McCarson KE, Goldstein BD. Release of substance $P$ into the superficial dorsal horn following nociceptive activation of the hindpaw of the rat. Brain Res 1991;568:109-15.

17. Henry JL. Effects of substance $P$ on functionally identified units in cat spinal cord. Brain Res 1976;114:439-51.

18. Randic M, Urban L. Slow excitatory transmission in rat spinal dorsal horn and the effects of capsaicin. Acta Physiol Hung 1987;69:375-92.

19. De Koninck Y, Henry JL. Substance P-mediated slow excitatory postsynaptic potential elicited in dorsal horn neurons in vivo by noxious stimulation. Proc Natl Acad Sci USA 1991;88:11344-8

20. Cao YQ, Mantyh PW, Carlson EJ, Gillespie AM, Epstein CJ, Basbaum AI. Primary afferent tachykinins are required to experience moderate to intense pain. Nature 1998;392:390-4.

21. Battaglia G, Rustioni A. Coexistence of glutamate and substance $P$ in dorsal root ganglion neurons of the rat and monkey. J Comp Neurol 1988;277:302-12.

22. De Biasi S, Rustioni A. Glutamate and substance $P$ coexist in primary afferent terminals in the superficial laminae of spinal cord. Proc Natl Acad Sci USA 1988;85:7820-4.

23. Suarez-Roca H, Abdullah L, Zuniga J, Madison S, Maixner W. Multiphasic effect of morphine on the release of substance $\mathrm{P}$ from rat trigeminal nucleus slices. Brain Res 1992;579:187-94.

24. Kuraishi Y, Hirota N, Sugimoto M, Satoh M, Takagi H. Effects of morphine on noxious stimuli-induced release of substance $\mathrm{P}$ from rabbit dorsal horn in vivo. Life Sci 1983;33:693-6.

25. Brodin E, Linderoth B, Gazelius B, Ungerstedt U. In vivo release of substance $\mathrm{P}$ in cat dorsal horn studied with microdialysis. Neurosci Lett 1987;76:357-62.

26. Duggan AW, Hendry IA. Laminar localization of the sites of release of immunoreactive substance $\mathrm{P}$ in the dorsal horn with antibody-coated microelectrodes. Neurosci Lett 1986;68:134-40.

27. Maggi CA. The mammalian tachykinin receptors. Gen Pharmacol 1995;26:911-44.

28. Garland AM, Grady EF, Payan DG, Vigna SR, Bunnett NW. Agonistinduced internalization of the substance $\mathrm{P}$ (NK1) receptor expressed in epithelial cells. Biochem J 1994;3031:177-86.

29. Grady EF, Garland AM, Gamp PD, Lovett M, Payan DG,

Bunnett NW. Delineation of the endocytic pathway of substance P and its seven-transmembrane domain NK1 receptor. Mol Biol Cell 1995;6:509-24.

30. Mantyh PW, Allen CJ, Ghilardi JR, et al. Rapid endocytosis of a $G$ protein-coupled receptor: substance $P$ evoked internalization of its receptor in the rat striatum in vivo. Proc Natl Acad Sci USA 1995;92:2622-6

31. Mantyh PW, DeMaster E, Malhotra A, et al. Receptor endocytosis and dendrite reshaping in spinal neurons after somatosensory stimulation. Science 1995;268:1629-32.

32. Abbadie C, Trafton J, Liu H, Mantyh PW, Basbaum AI. Inflammation increases the distribution of dorsal horn neurons that internalize the neurokinin-1 receptor in response to noxious and non-noxious stimulation. J Neurosci 1997;17:8049-60.

33. Trafton JA, Abbadie C, Marchand S, Mantyh PW, Basbaum AI. Spinal opioid analgesia: how critical is the regulation of substance $\mathrm{P}$ signaling? J Neurosci 1999;19:9642-53.

34. Liu H, Brown JL, Jasmin L, et al. Synaptic relationship between substance $P$ and the substance $P$ receptor: light and electron microscopic characterization of the mismatch between neuropeptides and their receptors. Proc Natl Acad Sci USA 1994;91:1009-13.
35. Aicher SA, Punnoose A, Goldberg A. Mu-opioid receptors often colocalize with the substance $\mathrm{P}$ receptor (NK1) in the trigeminal dorsal horn. J Neurosci 2000;20:4345-54.

36. Li J, Wang D, Kaneko T, Shigemoto R, Nomura S, Mizuno N. The relationship between neurokinin-1 receptor and substance $\mathrm{P}$ in the medullary dorsal horn. A light and electron microscopic immunohistochemical study in the rat. Neurosci Res 2000;36:327-34.

37. McLeod AL, Krause JE, Cuello AC, Ribeiro-da-Silva A. Preferential synaptic relationships between substance P-immunoreactive boutons and neurokinin 1 receptor sites in the rat spinal cord. Proc Natl Acad Sci USA 1998;95:15775-80.

38. Brown JL, Liu H, Maggio JE, Vigna SR, Mantyh PW, Basbaum AI. Morphological characterization of substance $\mathrm{P}$ receptorimmunoreactive neurons in the rat spinal cord and trigeminal nucleus caudalis. J Comp Neurol 1995;356:327-44.

39. Naim M, Spike RC, Watt C, Shehab SA, Todd AJ. Cells in laminae III and IV of the rat spinal cord that possess the neurokinin-1 receptor and have dorsally directed dendrites receive a major synaptic input from tachykinin-containing primary afferents. J Neurosci 1997; 17:5536-48.

40. Allen BJ, Rogers SD, Ghilardi JR, et al. Noxious cutaneous thermal stimuli induce a graded release of endogenous substance $P$ in the spinal cord: imaging peptide action in vivo. J Neurosci 1997;17:5921-7.

41. Honore P, Menning PM, Rogers SD, et al. Spinal substance P receptor expression and internalization in acute, short-term, and long-term inflammatory pain states. J Neurosci 1999;19:7670-8.

42. Allen BJ, Li J, Menning PM, et al. Primary afferent fibers that contribute to increased substance $P$ receptor internalization in the spinal cord after injury. J Neurophysiol 1999;81:1379-90.

43. Schwei MJ, Honore P, Rogers SD, et al. Neurochemical and cellular reorganization of the spinal cord in a murine model of bone cancer pain. J Neurosci 1999;19:10886-97.

44. Neumann S, Doubell TP, Leslie T, Woolf CJ. Inflammatory pain hypersensitivity mediated by phenotypic switch in myelinated primary sensory neurons. Nature 1996;384:360-4.

45. Hunt SP, Kelly JS, Emson PC, Kimmel JR, Miller RJ, Wu JY. An immunohistochemical study of neuronal populations containing neuropeptides or gamma-aminobutyrate within the superficial layers of the rat dorsal horn. Neuroscience 1981;6:1883-98.

46. Johansson $\mathrm{O}$, Hokfelt $\mathrm{T}$, Pernow $\mathrm{B}$, et al. Immunohistochemical support for three putative transmitters in one neuron: coexistence of 5-hydroxytryptamine, substance P- and thyrotropin releasing hormonelike immunoreactivity in medullary neurons projecting to the spinal cord. Neuroscience 1981;6:1857-81.

47. Menétrey D, Basbaum AI. The distribution of substance P-, enkephalin- and dynorphin-immunoreactive neurons in the medulla of the rat and their contribution to bulbospinal pathways. Neuroscience 1987;23:173-87.

48. Heath MJ, Womack MD, MacDermott AB. Substance P elevates intracellular calcium in both neurons and glial cells from the dorsal horn of the spinal cord. J Neurophysiol 1994;72:1192-8.

49. Garland AM, Grady EF, Lovett M, et al. Mechanisms of desensitization and resensitization of $\mathrm{G}$ protein-coupled neurokinin-1 and neurokinin-2 receptors. Mol Pharmacol 1996;49:438-46.

50. Kitsukawa Y, Turner RJ, Pradhan TK, Jensen RT. Gastric chief cells possess NK1 receptors which mediate pepsinogen secretion and are regulated by agents that increase cAMP and phospholipase C. Biochim Biophys Acta 1996;1312:105-16.

51. McConalogue K, Corvera CU, Gamp PD, Grady EF, Bunnett NW. Desensitization of the neurokinin-1 receptor (NK1-R) in neurons: effects of substance P on the distribution of NK1-R, Galphaq/11, G-protein receptor kinase-2/3, and beta-arrestin-1/2. Mol Biol Cell 1998;9:2305-24.

52. Lamotte C, Pert CB, Snyder SH. Opiate receptor binding in primate spinal cord: distribution and changes after dorsal root section. Brain Res 1976;112:407-12.

53. Fields HL, Emson PC, Leigh BK, Gilbert RF, Iversen LL. Multiple 
opiate receptor sites on primary afferent fibres. Nature (Lond) 1980;284:351-3.

54. Gamse R, Holzer P, Lembeck F. Indirect evidence for presynaptic location of opiate receptors on chemosensitive primary sensory neurones. Naunyn Schmiedebergs Arch Pharmacol 1979;308:281-5.

55. Nagy JI, Hunt SP, Iversen LL, Emson PC. Biochemical and anatomical observations on the degeneration of peptide-containing primary afferent neurons after neonatal capsaicin. Neuroscience 1981;6:1923-34.

56. Gouarderes C, Beaudet A, Zajac JM, Cros J, Quirion R. High resolution radioautographic localization of $\left[{ }^{125} \mathrm{I}\right] \mathrm{FK}-33-824-$ labelled mu opioid receptors in the spinal cord of normal and deafferented rats. Neuroscience 1991;43:197-209.

57. Besse D, Lombard MC, Perrot S, Besson JM. Regulation of opioid binding sites in the superficial dorsal horn of the rat spinal cord following loose ligation of the sciatic nerve: comparison with sciatic nerve section and lumbar dorsal rhizotomy. Neuroscience 1992;50:921-33.

58. Dado RJ, Law PY, Loh HH, Elde R. Immunofluorescent identification of a delta-opioid receptor on primary afferent nerve terminals. Neuroreport 1993;5:341-4.

59. Ding YQ, Nomura S, Kaneko T, Mizuno N. Co-localization of muopioid receptor-like and substance P-like immunoreactivities in axon terminals within the superficial layers of the medullary and spinal dorsal horns of the rat. Neurosci Lett 1995;198:45-8.

60. Arvidsson U, Riedl M, Chakrabarti S, et al. Distribution and targeting of a mu-opioid receptor (MOR1) in brain and spinal cord. J Neurosci 1995; 15:3328-41.

61. Ji RR, Zhang Q, Law PY, Low HH, Elde R, Hökfelt T. Expression of mu-, delta-, and kappa-opioid receptor-like immunoreactivities in rat dorsal root ganglia after carrageenan-induced inflammation. J Neurosci 1995;15:8156-66.

62. Mansour A, Fox CA, Burke S, Akil H, Watson SJ. Immunohistochemical localization of the cloned mu opioid receptor in the rat CNS. J Chem Neuroanat 1995;8:283-305.

63. Li JL, Kaneko T, Mizuno N. Effects of peripheral nerve ligation on expression of mu-opioid receptor in sensory ganglion neurons: an immunohistochemical study in dorsal root and nodose ganglion neurons of the rat. Neurosci Lett 1996;214:91-4.

64. Zhang Q, Schaffer M, Elde R, Stein C. Effects of neurotoxins and hindpaw inflammation on opioid receptor immunoreactivities in dorsal root ganglia. Neuroscience 1998;85:281-91.

65. Zhang X, Bao L, Shi TJ, Ju G, Elde R, Hokfelt T. Down-regulation of mu-opioid receptors in rat and monkey dorsal root ganglion neurons and spinal cord after peripheral axotomy. Neuroscience 1998;82:223-40.

66. Maekawa K, Minami M, Yabuuchi K, et al. In situ hybridization study of mu- and kappa-opioid receptor mRNAs in the rat spinal cord and dorsal root ganglia. Neurosci Lett 1994;168:97-100.

67. Mansour A, Fox CA, Burke S, et al. Mu, delta, and kappa opioid receptor mRNA expression in the rat CNS: an in situ hybridization study. J Comp Neurol 1994;350:412-38.

68. Schafer MK, Bette M, Romeo H, Schwaeble W, Weihe E. Localization of kappa-opioid receptor mRNA in neuronal subpopulations of rat sensory ganglia and spinal cord. Neurosci Lett 1994;167:137-40.

69. Minami M, Maekawa K, Yabuuchi K, Satoh M. Double in situ hybridization study on coexistence of mu-, delta- and kappa-opioid receptor mRNAs with preprotachykinin A mRNA in the rat dorsal root ganglia. Brain Res Mol Brain Res 1995;30:203-10.

70. Werz MA, Grega DS, MacDonald RL. Actions of mu, delta and kappa opioid agonists and antagonists on mouse primary afferent neurons in culture. J Pharmacol Exp Ther 1987;243:258-63.

71. Schroeder JE, Fischbach PS, Zheng D, McCleskey EW. Activation of $\mathrm{mu}$ opioid receptors inhibits transient high- and low-threshold $\mathrm{Ca}^{2+}$ currents, but spares a sustained current. Neuron 1991;6:13-20.

72. Rusin KI, Moises HC. Mu-opioid receptor activation reduces multiple components of high-threshold calcium current in rat sensory neurons. J Neurosci 1995; 15:4315-27.
73. Taddese A, Nah SY, McCleskey EW. Selective opioid inhibition of small nociceptive neurons. Science 1995;270:1366-9.

74. Jessell TM, Iversen LL. Opiate analgesics inhibit substance P release from rat trigeminal nucleus. Nature 1977;268:549-51.

75. Hirota N, Kuraishi Y, Hino Y, Sato Y, Satoh M, Takagi H. Met-enkephalin and morphine but not dynorphin inhibit noxious stimuli- induced release of substance $\mathrm{P}$ from rabbit dorsal horn in situ. Neuropharmacology 1985;24:567-70.

76. Aimone LD, Yaksh TL. Opioid modulation of capsaicin-evoked release of substance $\mathrm{P}$ from rat spinal cord in vivo. Peptides 1989;10:1127-31.

77. Morton CR, Hutchison WD, Duggan AW, Hendry IA. Morphine and substance P release in the spinal cord. Exp Brain Res 1990;82:89-96.

78. Lang CW, Duggan AW, Hope PJ. Analgesic doses of morphine do not reduce noxious stimulus-evoked release of immunoreactive neurokinins in the dorsal horn of the spinal cat. Br J Pharmacol 1991;103:1871-6.

79. Mauborgne A, Lutz O, Legrand JC, Hamon M, Cesselin F. Opposite effects of delta and mu opioid receptor agonists on the in vitro release of substance P-like material from the rat spinal cord. J Neurochem 1987;48:529-37.

80. Cano G, Arcaya JL, Gomez G, Maixner W, Suarez-Roca H. Multiphasic morphine modulation of substance $\mathrm{P}$ release from capsaicin-sensitive primary afferent fibers. Neurochem Res 1999;24:1203-7.

81. Kayser V, Guilbaud G. The analgesic effects of morphine, but not those of the enkephalinase inhibitor thiorphan, are enhanced in arthritic rats. Brain Res 1983;267:131-8.

82. Miaskowski C, Sutters KA, Taiwo YO, Levine JD. Comparison of the antinociceptive and motor effects of intrathecal opioid agonists in the rat. Brain Res 1991;553:105-9.

83. Donnerer J, Schuligoi R, Stein C. Increased content and transport of substance $\mathrm{P}$ and calcitonin gene-related peptide in sensory nerves innervating inflamed tissue: evidence for a regulatory function of nerve growth factor in vivo. Neuroscience 1992;49:693-8.

84. Hanesch U, Pfrommer U, Grubb BD, Heppelmann B, Schaible HG. The proportion of CGRP-immunoreactive and SP-mRNA containing dorsal root ganglion cells is increased by a unilateral inflammation of the ankle joint of the rat. Regul Pept 1993;46:202-3.

85. Mapp PI, Terenghi G, Walsh DA, et al. Monoarthritis in the rat knee induces bilateral and time-dependent changes in substance $\mathrm{P}$ and calcitonin gene-related peptide immunoreactivity in the spinal cord. Neuroscience 1993;57:1091-6.

86. Schafer MK, Nohr D, Krause JE, Weihe E. Inflammation-induced upregulation of NK1 receptor mRNA in dorsal horn neurones. Neuroreport 1993;4:1007-10.

87. McCarson KE, Krause JE. NK-1 and NK-3 type tachykinin receptor mRNA expression in the rat spinal cord dorsal horn is increased during adjuvant or formalin-induced nociception. J Neurosci 1994;14:712-20

88. McCarson KE, Krause JE. The formalin-induced expression of tachykinin peptide and neurokinin receptor messenger RNAs in rat sensory ganglia and spinal cord is modulated by opiate preadministration. Neuroscience 1995;64:729-39.

89. Abbadie C, Brown JL, Mantyh PW, Basbaum AI. Spinal cord substance $\mathrm{P}$ receptor immunoreactivity increases in both inflammatory and nerve injury models of persistent pain. Neuroscience 1996;70:201-9.

90. Carstens E, Tulloch I, Zieglgansberger W, Zimmermann M. Presynaptic excitability changes induced by morphine in single cutaneous afferent C- and A-fibers. Pflügers Arch 1979;379:143-7.

91. Sastry BR. Potentiation of presynaptic inhibition of nociceptive pathways as a mechanism for analgesia. Can J Physiol Pharmacol 1980;58:97-101

92. Murase K, Nedeljkov V, Randic M. The actions of neuropeptides on dorsal horn neurons in the rat spinal cord slice preparation: an intracellular study. Brain Res 1982;234:170-6.

93. Yoshimura M, North RA. Substantia gelatinosa neurones hyperpolarized in vitro by enkephalin. Nature 1983;305:529-30 
94. Jeftinija S. Enkephalins modulate excitatory synaptic transmission in the superficial dorsal horn by acting at mu-opioid receptor sites. Brain Res 1988;460:260-8.

95. Hori Y, Endo K, Takahashi T. Presynaptic inhibitory action of enkephalin on excitatory transmission in superficial dorsal horn of rat spinal cord. J Physiol (Lond) 1992;450:673-85.

96. Glaum SR, Miller RJ, Hammond DL. Inhibitory actions of delta 1-, delta 2-, and mu-opioid receptor agonists on excitatory transmission in lamina II neurons of adult rat spinal cord. J Neurosci 1994;14:4965-71.

97. Grudt TJ, Williams JT. Mu-Opioid agonists inhibit spinal trigeminal substantia gelatinosa neurons in guinea pig and rat. J Neurosci 1994;14:1646-54.

98. Malcangio M, Bowery NG. GABA and its receptors in the spinal cord. Trends Pharmacol Sci 1996;17:457-62.

99. Misgeld U, Bijak M, Jarolimek W. A physiological role for $\mathrm{GABA}_{B}$ receptors and the effects of baclofen in the mammalian central nervous system. Prog Neurobiol 1995;46:423-62.

100. Malcangio M, Bowery NG. Possible therapeutic application of $\mathrm{GABA}_{\mathrm{B}}$ receptor agonists and antagonists. Clin Neuropharmacol 1995; 18:285-305.

101. Singer E, Placheta $P$. Reduction of $\left[{ }^{3} \mathrm{H}\right]$ muscimol binding sites in rat dorsal spinal cord after neonatal capsaicin treatment. Brain Res 1980;202:484-7.

102. Price GW, Wilkin GP, Turnbull MJ, Bowery NG. Are baclofensensitive $\mathrm{GABA}_{\mathrm{B}}$ receptors present on primary afferent terminals of the spinal cord? Nature 1984;307:71-4.

103. Price GW, Kelly JS, Bowery NG. The location of GABA $A_{B}$ receptor binding sites in mammalian spinal cord. Synapse 1987;1:530-8.

104. Kaupmann K, Huggel K, Heid J, et al. Expression cloning of $\mathrm{GABA}_{B}$ receptors uncovers similarity to metabotropic glutamate receptors. Nature 1997;386:239-46.

105. Persohn E, Malherbe P, Richards JG. In situ hybridization histochemistry reveals a diversity of $\mathrm{GABA}_{\mathrm{A}}$ receptor subunit mRNAs in neurons of the rat spinal cord and dorsal root ganglia. Neuroscience 1991;42:497-507.

106. Desarmenien M, Feltz P, Occhipinti G, Santangelo F, Schlichter R. Coexistence of $\mathrm{GABA}_{\mathrm{A}}$ and $\mathrm{GABA}_{\mathrm{B}}$ receptors on Adelta and $\mathrm{C}$ primary afferents. Br J Pharmacol 1984;81:327-33.

107. Kangrga I, Jiang MC, Randic M. Actions of (-)-baclofen on rat dorsal horn neurons. Brain Res 1991;562:265-75.

108. Ataka T, Kumamoto E, Shimoji K, Yoshimura M. Baclofen inhibits more effectively $\mathrm{C}$-afferent than Adelta-afferent glutamatergic transmission in substantia gelatinosa neurons of adult rat spinal cord slices. Pain 2000;86:273-82.

109. Piercey MF, Hollister RP. Effects of intravenous baclofen on dorsal horn neurons of spinal cats. Eur J Pharmacol 1979;53:379-82.

110. Henry JL. Effects of intravenously administered enantiomers of baclofen on functionally identified units in lumbar dorsal horn of the spinal cat. Neuropharmacology 1982;21:1073-83.

111. Dickenson AH, Brewer CM, Hayes NA. Effects of topical baclofen on C fibre-evoked neuronal activity in the rat dorsal horn. Neuroscience 1985; 14:557-62.

112. Sivilotti L, Woolf CJ. The contribution of $\mathrm{GABA}_{\mathrm{A}}$ and glycine receptors to central sensitization: disinhibition and touch-evoked allodynia in the spinal cord. J Neurophysiol 1994;72:169-79.

113. Rees H, Sluka KA, Westlund KN, Willis WD. The role of glutamate and GABA receptors in the generation of dorsal root reflexes by acute arthritis in the anaesthetized rat. J Physiol (Lond) 1995;484:437-45.

114. Curtis DR, Lodge D, Bornstein JC, Peet MJ. Selective effects of (-)-baclofen on spinal synaptic transmission in the cat. Exp Brain Res 1981;42:158-70.

115. Curtis DR, Lacey G. GABA receptor-mediated spinal inhibition. Neuroreport 1994;5:540-2.

116. Morton CR, Hutchison WD, Lacey G. Baclofen and the release of neuropeptides in the cat spinal cord. Eur J Neurosci 1992;4:243-50.

117. Malcangio M, Bowery NG. Gamma-aminobutyric acid-B, but not gamma-aminobutyric acid-A receptor activation, inhibits electrically evoked substance P-like immunoreactivity release from the rat spinal cord in vitro. J Pharmacol Exp Ther 1993;266:1490-6.

118. Bourgoin S, Pohl M, Benoliel JJ, et al. Gamma-aminobutyric acid, through $\mathrm{GABA}_{\mathrm{A}}$ receptors, inhibits the potassium-stimulated release of calcitonin gene-related peptide- but not that of substance P-like material from rat spinal cord slices. Brain Res 1992;583:344-8.

119. Sawynok J, Kato N, Havlicek V, LaBella FS. Lack of effect of baclofen on substance $\mathrm{P}$ and somatostatin release from the spinal cord in vitro. Naunyn Schmiedebergs Arch Pharmacol 1982;319:78-81.

120. Santicioli P, Del Bianco E, Tramontana M, Maggi CA. Adenosine inhibits action potential-dependent release of calcitonin gene-related peptide- and substance P-like immunoreactivities from primary afferents in rat spinal cord. Neurosci Lett 1992;144:211-4.

121. Carlton SM, McNeill DL, Chung K, Coggeshall RE. A light and electron microscopic level analysis of calcitonin gene-related peptide (CGRP) in the spinal cord of the primate: an immunohistochemical study. Neurosci Lett 1987;82:145-50.

122. Teoh $\mathrm{H}$, Malcangio M, Bowery NG. GABA, glutamate and substance P-like immunoreactivity release: effects of novel $\mathrm{GABA}_{\mathrm{B}}$ antagonists. Br J Pharmacol 1996;118:1153-60.

123. Dunlap K. Functional and pharmacological differences between two types of GABA receptor on embryonic chick sensory neurons. Neurosci Lett 1984;47:265-70.

124. Curtis DR, Gynther BD, Lacey G, Beattie DT. Baclofen: reduction of presynaptic calcium influx in the cat spinal cord in vivo. Exp Brain Res 1997;113:520-33.

125. Levy RA. The role of GABA in primary afferent depolarization. Prog Neurobiol 1977;9:211-67.

126. Kaila K. Ionic basis of $\mathrm{GABA}_{\mathrm{A}}$ receptor channel function in the nervous system. Prog Neurobiol 1994;42:489-537.

127. Riley RC, Trafton JA, Chi S-I. Basbaum AI. Presynaptic control of nociceptor signaling: differential influence of mu opioid and GABAergic systems. Neuroscience (In press)

128. Marvizon JC, Grady EF, Stefani E, Bunnett NW, Mayer EA Substance $\mathrm{P}$ release in the dorsal horn assessed by receptor internalization: NMDA receptors counteract a tonic inhibition by $\mathrm{GABA}_{\mathrm{B}}$ receptors. Eur J Neurosci 1999;11:417-26.

129. Wilson PR, Yaksh TL. Baclofen is antinociceptive in the spinal intrathecal space of animals. Eur J Pharmacol 1978;51:323-30.

130. Hammond DL, Drower EJ. Effects of intrathecally administered THIP, baclofen and muscimol on nociceptive threshold. Eur J Pharmacol 1984;103:121-5.

131. Thomas DA, Navarrete IM, Graham BA, McGowan MK, Hammond DL. Antinociception produced by systemic R(+)-baclofen hydrochloride is attenuated by CGP 35348 administered to the spinal cord or ventromedial medulla of rats. Brain Res 1996;718:129-37.

132. Malcangio M, Bowery NG. Spinal cord SP release and hyperalgesia in monoarthritic rats: involvement of the $\mathrm{GABA}_{\mathrm{B}}$ receptor system. Br J Pharmacol 1994;113:1561-6.

133. Dirig DM, Yaksh TL. Intrathecal baclofen and muscimol, but not midazolam, are antinociceptive using the rat-formalin model. J Pharmacol Exp Ther 1995;275:219-27.

134. Hwang JH, Yaksh TL. The effect of spinal GABA receptor agonists on tactile allodynia in a surgically-induced neuropathic pain model in the rat. Pain 1997; 70:15-22

135. Cui JG, Linderoth B, Meyerson BA. Effects of spinal cord stimulation on touch-evoked allodynia involve GABAergic mechanisms. An experimental study in the mononeuropathic rat. Pain 1996;66:287-95.

136. Glazer EJ, Basbaum AI. Immunohistochemical localization of leucineenkephalin in the spinal cord of the cat: enkephalin-containing marginal neurons and pain modulation. J Comp Neurol 1981;196:377-89.

137. Ruda MA. Opiates and pain pathways: demonstration of enkephalin synapses on dorsal horn projection neurons. Science 1982;215:1523-5

138. Sumal KK, Pickel VM, Miller RJ, Reis DJ. Enkephalin-containing neurons in substantia gelatinosa of spinal trigeminal complex: 
ultrastructure and synaptic interaction with primary sensory afferents. Brain Res 1982;248:223-36.

139. Ma W, Ribeiro-da-Silva A, De Koninck Y, Radhakrishnan V, Cuello AC, Henry JL. Substance P and enkephalin immunoreactivities in axonal boutons presynaptic to physiologically identified dorsal horn neurons. An ultrastructural multiple-labelling study in the cat. Neuroscience 1997;77:793-811.

140. Tashiro T, Takahashi O, Satoda T, Matsushima R, Mizuno N. Immunohistochemical demonstration of coexistence of enkephalin-and substance P-like immunoreactivities in axonal components in the lumbar segments of cat spinal cord. Brain Res 1987;424:391-5.

141. Ribeiro-da-Silva A, Pioro EP, Cuello AC. Substance P- and enkephalin-like immunoreactivities are colocalized in certain neurons of the substantia gelatinosa of the rat spinal cord: an ultrastructural double-labeling study. J Neurosci 1991;11:1068-80.

142. Senba E, Yanaihara C, Yanaihara N, Tohyama M. Co-localization of substance $\mathrm{P}$ and Met-enkephalin-Arg ${ }^{6}-\mathrm{Gly}^{7}-\mathrm{Leu}^{8}$ in the intraspinal neurons of the rat, with special reference to the neurons in the substantia gelatinosa. Brain Res 1988;453:110-6.

143. Agnati LF, Zoli M, Stromberg I, Fuxe K. Intercellular communication in the brain: wiring versus volume transmission. Neuroscience 1995;69:711-26.

144. Zoli M, Torri C, Ferrari R, et al. The emergence of the volume transmission concept. Brain Res Brain Res Rev 1998;26:136-47.

145. Henry JL. Role of circulating opioids in the modulation of pain. Ann NY Acad Sci 1986;467:169-81.

146. Barber RP, Vaughn JE, Saito K, McLaughlin BJ, Roberts E. GABAergic terminals are presynaptic to primary afferent terminals in the substantia gelatinosa of the rat spinal cord. Brain Res 1978;141:35-55.

147. Basbaum AI, Glazer EJ, Oertel W. Immunoreactive glutamic acid decarboxylase in the trigeminal nucleus caudalis of the cat: a light- and electron-microscopic analysis. Somatosens Res 1986;4:77-94.

148. Todd AJ, Lochhead V. GABA-like immunoreactivity in type I glomeruli of rat substantia gelatinosa. Brain Res 1990;514:171-4.

149. Alvarez FJ, Kavookjian AM, Light AR. Synaptic interactions between GABA-immunoreactive profiles and the terminals of functionally defined myelinated nociceptors in the monkey and cat spinal cord. J Neurosci 1992;12:2901-17.

150. Sakamoto H, Atsumi S. Interaction between substance P-immunoreactive central terminals and gamma-aminobutyric acidimmunoreactive elements in synaptic glomeruli in the lamina II of the chicken spinal cord. Neurosci Res 1995;23:335-43.

151. Carlton SM, Hayes ES. Light microscopic and ultrastructural analysis of GABA-immunoreactive profiles in the monkey spinal cord. J Comp Neurol 1990;300:162-82.

152. Hayes ES, Carlton SM. Primary afferent interactions: analysis of calcitonin gene-related peptide-immunoreactive terminals in contact with unlabeled and GABA-immunoreactive profiles in the monkey dorsal horn. Neuroscience 1992;47:873-96.

153. Bernardi PS, Valtschanoff JG, Weinberg RJ, Schmidt HH, Rustioni A. Synaptic interactions between primary afferent terminals and GABA and nitric oxide-synthesizing neurons in superficial laminae of the rat spinal cord. J Neurosci 1995; 15:1363-71.

154. Todd AJ. GABA and glycine in synaptic glomeruli of the rat spinal dorsal horn. Eur J Neurosci 1996;8:2492-8.

155. Todd AJ, McKenzie J. GABA-immunoreactive neurons in the dorsal horn of the rat spinal cord. Neuroscience 1989;31:799-806.

156. Millhorn DE, Hokfelt T, Seroogy K, Oertel W, Verhofstad AA, $\mathrm{Wu} \mathrm{JY}$. Immunohistochemical evidence for colocalization of gamma-aminobutyric acid and serotonin in neurons of the ventral medulla oblongata projecting to the spinal cord. Brain Res 1987;410:179-85.

157. Castro-Lopes JM, Tavares I, Tölle TR, Coimbra A. Carrageenaninduced inflammation of the hind foot provokes a rise of GABAimmunoreactive cells in the rat spinal cord that is prevented by peripheral neurectomy or neonatal capsaicin treatment. Pain 1994;56:193-201.

158. Wei F, Zhao ZQ. Blockade of capsaicin-induced reduction of GABAimmunoreactivity by spantide in cat spinal superficial dorsal horn. Neuroscience 1996;71:277-83.

159. Littlewood NK, Todd AJ, Spike RC, Watt C, Shehab SA. The types of neuron in spinal dorsal horn which possess neurokinin-1 receptors. Neuroscience 1995;66:597-608.

160. Castro AR, Bowery N, Castro-Lopes JM. Baclofen and midazolam alter c-fos induction by peripheral noxious or innocuous stimulation in the spinal cord of normal and monoarthritic rats. Neuropharmacology 1999;38:1775-88

161. Saria A. The tachykinin NK1 receptor in the brain: pharmacology and putative functions. Eur J Pharmacol 1999;375:51-60.

162. Hara K, Saito Y, Kirihara Y, Yamada Y, Sakura S, Kosaka Y. The interaction of antinociceptive effects of morphine and GABA receptor agonists within the rat spinal cord. Anesth Analg 1999;89:422-7.

163. Murtra P, Sheasby AM, Hunt SP, De Felipe C. Rewarding effects of opiates are absent in mice lacking the receptor for substance $\mathrm{P}$. Nature 2000;405:180-3.

164. Gordon NC, Gear RW, Heller PH, Paul S, Miaskowski C, Levine JD. Enhancement of morphine analgesia by the $\mathrm{GABA}_{\mathrm{B}}$ agonist baclofen. Neuroscience 1995;69:345-9.

165. Jasmin L, Wang H, Tarczy-Hornoch K, Levine JD, Basbaum AI. Differential effects of morphine on noxious stimulus-evoked fos-like immunoreactivity in subpopulations of spinoparabrachial neurons. J Neurosci 1994;14:7252-60. 


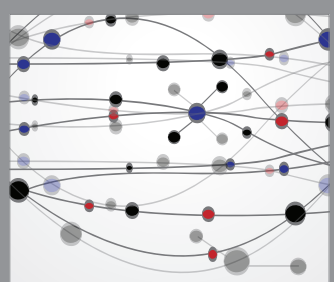

The Scientific World Journal
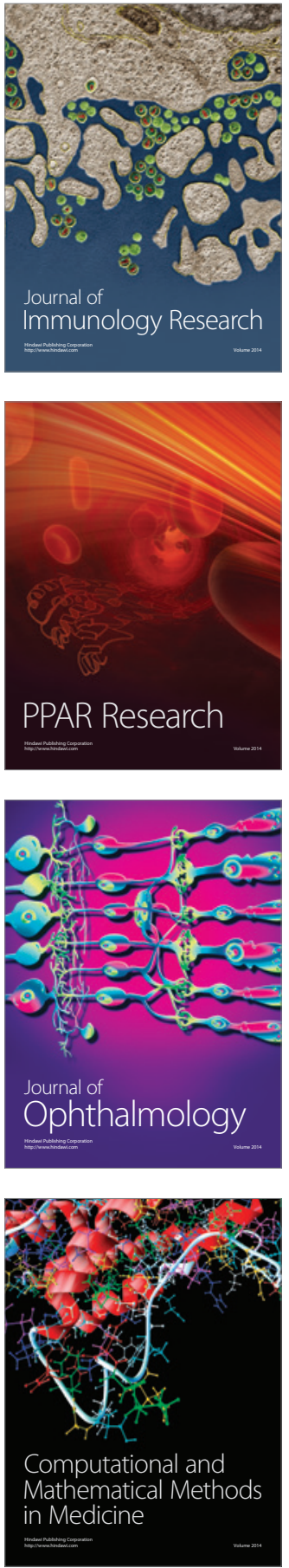

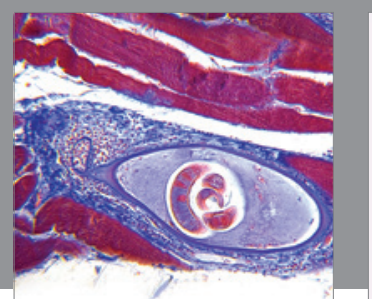

Gastroenterology Research and Practice

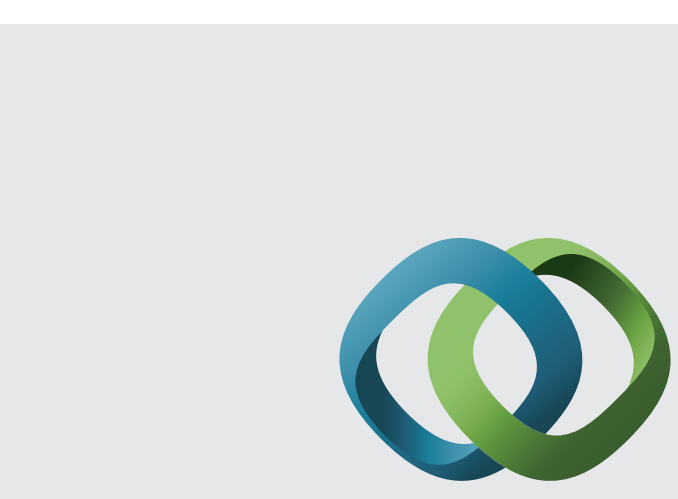

\section{Hindawi}

Submit your manuscripts at

http://www.hindawi.com
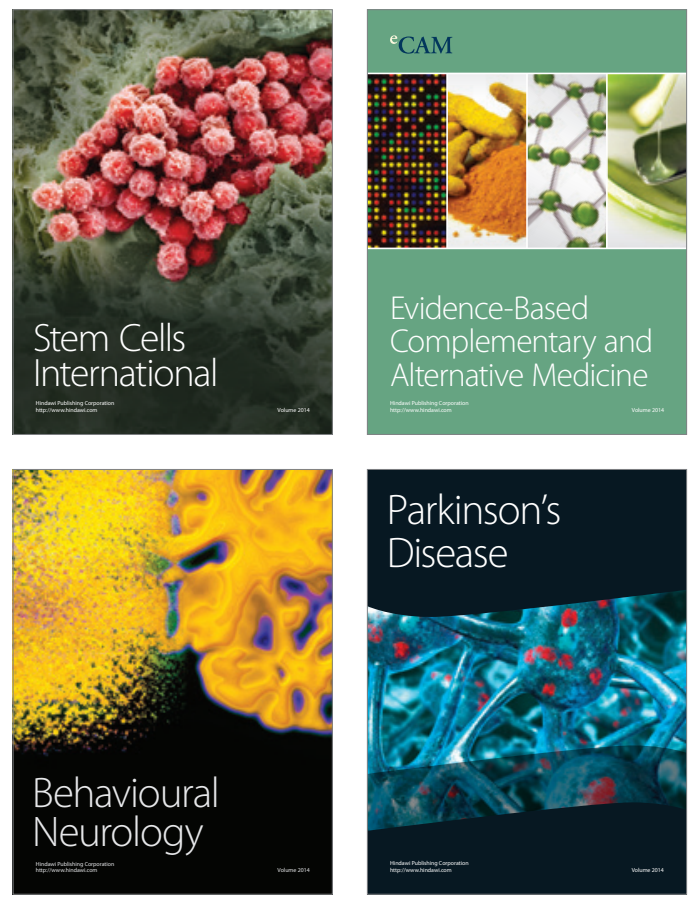
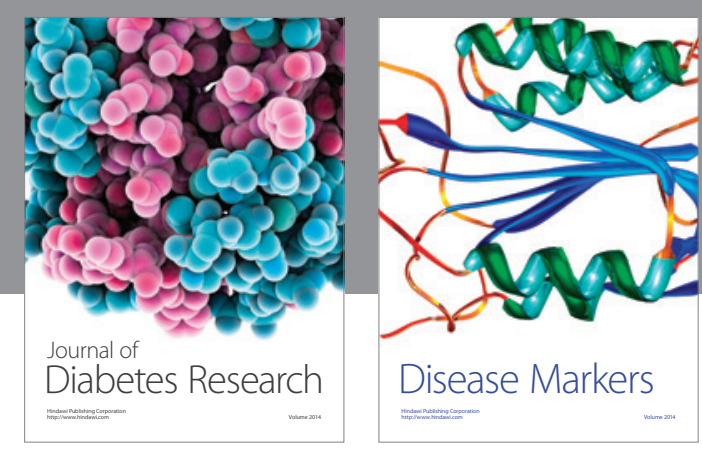

Disease Markers
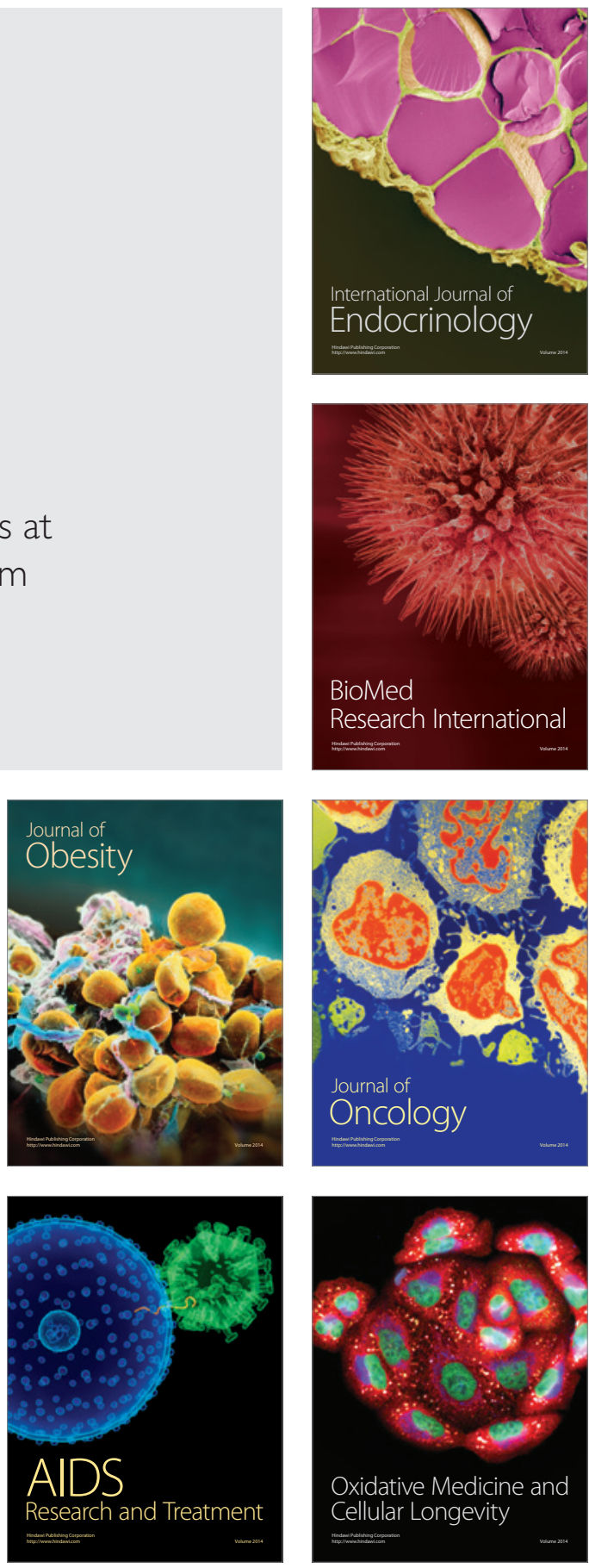